\title{
The Protective Role of Butyrate against Obesity and Obesity-Related Diseases
}

\author{
Serena Coppola ${ }^{1,2,+}+\mathbb{D}$, Carmen Avagliano ${ }^{3,+}$, Antonio Calignano ${ }^{3}$ and Roberto Berni Canani ${ }^{1,2,4,5, *(\mathbb{D})}$ \\ 1 Department of Translational Medical Science, University of Naples Federico II, 80131 Naples, Italy; \\ serenacoppola@mail.com \\ 2 ImmunoNutriton Lab at CEINGE Advanced Biotechnologies, University of Naples Federico II, \\ 80131 Naples, Italy \\ 3 Department of Pharmacy, University of Naples Federico II, 80131 Naples, Italy; \\ carmen.avagliano@unina.it (C.A.); calignan@unina.it (A.C.) \\ 4 European Laboratory for the Investigation of Food Induced Diseases (ELFID), \\ University of Naples Federico II, 80131 Naples, Italy \\ 5 Task Force on Microbiome Studies, University of Naples Federico II, 80131 Naples, Italy \\ * Correspondence: berni@unina.it; Tel.: +39-081-7462680 \\ + These authors contributed equally to this work.
}

check for updates

Citation: Coppola, S.; Avagliano, C.; Calignano, A.; Berni Canani, R. The Protective Role of Butyrate against Obesity and Obesity-Related Diseases. Molecules 2021, 26, 682. https://doi.org/10.3390/molecules 26030682

\section{Academic Editor:}

Ryszard Amarowicz

Received: 7 January 2021

Accepted: 25 January 2021

Published: 28 January 2021

Publisher's Note: MDPI stays neutral with regard to jurisdictional claims in published maps and institutional affiliations.

Copyright: (c) 2021 by the authors. Licensee MDPI, Basel, Switzerland. This article is an open access article distributed under the terms and conditions of the Creative Commons Attribution (CC BY) license (https:/ / creativecommons.org/licenses/by/ $4.0 /)$.
Abstract: Worldwide obesity is a public health concern that has reached pandemic levels. Obesity is the major predisposing factor to comorbidities, including type 2 diabetes, cardiovascular diseases, dyslipidemia, and non-alcoholic fatty liver disease. The common forms of obesity are multifactorial and derive from a complex interplay of environmental changes and the individual genetic predisposition. Increasing evidence suggest a pivotal role played by alterations of gut microbiota (GM) that could represent the causative link between environmental factors and onset of obesity. The beneficial effects of GM are mainly mediated by the secretion of various metabolites. Short-chain fatty acids (SCFAs) acetate, propionate and butyrate are small organic metabolites produced by fermentation of dietary fibers and resistant starch with vast beneficial effects in energy metabolism, intestinal homeostasis and immune responses regulation. An aberrant production of SCFAs has emerged in obesity and metabolic diseases. Among SCFAs, butyrate emerged because it might have a potential in alleviating obesity and related comorbidities. Here we reviewed the preclinical and clinical data that contribute to explain the role of butyrate in this context, highlighting its crucial contribute in the diet-GM-host health axis.

Keywords: short-chain fatty acids; butyric acid; metabolic diseases; gut microbiota

\section{Introduction}

Obesity is a public health concern worldwide. It has been defined by the World Health Organization as abnormal or excessive fat accumulation that may impair health [1]. This condition has reached pandemic levels, in the last four decades its prevalence has tripled: about $39 \%$ of the world's adult population is actually overweight and $13 \%$ (11\% of men and $15 \%$ of women) is obese [1]. This health issue affects all age groups and countries of all income levels. Globally there are more people who are obese than underweight, this occurs in every area except parts of sub-Saharan Africa and Asia, and actually obesity is linked to more deaths worldwide than underweight [1]. The onset of obesity in childhood is a risk factor for adult obesity and is linked to significant negative physical and psychosocial consequences: last data reported that 38 million children under 5 years are overweight or obese and over 340 million children and adolescents are overweight or obese [1]. So, intervening in children is essential to change their weight trajectory and try to prevent adult obesity and his health sequelae. This largely preventable health threat is a risk factor for other metabolic diseases such as type 2 diabetes, cardiovascular diseases, dyslipidemia, non-alcoholic fatty liver disease, chronic kidney disease, obstructive sleep 
apnea and hypoventilation syndrome, mood disorders and physical disabilities [2]. A very small proportion of obesity cases result from monogenic alterations (syndromic and nonsyndromic), so the common forms of obesity are multifactorial and are most likely due to a complex interplay of environmental changes (obesogenic environment) and the individual genetic predisposition [3]. The main drivers of multifactorial obesity pathogenesis seem to be a long-term of energy discrepancy between too many calories consumed and an increase of sedentary behavior [4]. Behind this, the over-representation of genetic variants that favor overeating and/or low energy expenditure can be sought in the selective pressure that has most likely contributed to the evolution of a human genotype able to preserve the few foodstuffs available to survive in a long period of famine and then exposed to an increasingly obesogenic environment [5]. One of astonishing findings is the role played by human gut microbes (commonly defined as gut microbiota, GM) that could represent the causative link between environmental factors and the onset of obesity, since a growing body of evidence suggests that the set of microorganisms that live within the digestive tract, making up the GM, play a role in energy regulation and substrate metabolism [6]. Germ-free mice offer one of key finding for determining the role of the GM in energy balance: these experimental animal models are protected from diet-induced obesity when compared with conventional (colonized) counterparts, despite consuming more calories [7]. Furthermore, fecal transplant from obese humans to germ-free mice elicit more weight gain than mice that receive microbes from normal weight humans [8]. Dysbiosis, a condition of aberrant GM, induces metabolic, inflammatory and immune disturbances both locally and, consequent upon impaired gut barrier function, also systemically; so, the gut microecology could thus fill the gap between energy intake and expenditure by processing nutrients and regulating their access to and storage in the body, through the secretion control of hormones and mediators of energy homeostasis [9]. Conversely, being highly sensitive to environmental impacts, particularly to diet, the development of the GM may prove the target of choice in efforts to reduce the risk of obesity. The number of metagenomic data generated on obese subjects can lead to the erroneous claim that a bacterium is causally linked with the protection or the onset of this disease, in fact, the necessity for analyzing not only the presence of certain gut microorganisms but also their activity (including the metabolome) should be considered [10]. Among the factors which impact the GM, dietary compounds deeply affect the growth and metabolism of gut bacteria, since fermentation of nutrients is one core function of the intestinal microbes [11]. Within fermentation products an array of small organic metabolites is short-chain fatty acids (SCFAs) acetate, propionate and butyrate [12]. SCFAs are the primary end products of degradation of dietary fibers, the fraction of not digested carbohydrates $(\mathrm{CHO})$ by endogenous enzymes in the small intestine; in the context of indigestible $\mathrm{CHO}$ some fibers are not used by human gut microbes, such as cellulose, whereas some $\mathrm{CHO}$ are fermented by gut bacteria (such as resistant starch (RS)) but fall outside fibers definition [13]. The "Westernization" of lifestyles might lead to an increase in obesity levels, so GM investigation made progress in understanding the role of resident bacteria in relation to Western metabolic diseases [14]. Microbiota-accessible carbohydrates (MACs) are CHO available to gut microbes' degradation that are notably reduced in the Western-style diet, which is high in fat and simple $\mathrm{CHO}$ and low in fibers [15]; furthermore, evidence show that microbiota transplantation from mice fed a Western diet to germ-free mice transfers the obese phenotype [16]. Another consequence of MACs restriction, typical of Western diet, is a reduction in SCFAs production with the consequent loss of SCFAs benefits, potent regulatory molecules with vast physiological effects such as energy metabolism, intestinal homeostasis and immune responses regulation [13]. However, it is clear that three SCFAs differ substantially in their potential effects upon host physiology. Firstly, they differ in their fate and tissue distribution, with butyrate as the main energy source for colonocytes, propionate which contribute to liver gluconeogenesis and acetate that achieves the highest systemic concentrations in blood; secondly, they differ in the interaction with host proteins (e.g., inhibition of histone deacetylases by butyrate and propionate) and receptors [17]. Among SCFAs, butyrate 
emerged because it might have a potential in alleviating obesity and related metabolic complications typical of westernized countries [18]. For demonstration, a lower abundance of butyrate-producing microbes in humans has been associated with an increased risk of metabolic disease, showing its strength in mitigation of the metabolic disturbances of obesity [9]. This makes it particularly relevant to consider the microbial origin of this fermentation product and the potential for changes in diet and gut physiology to affect its relative production rates and concentrations. SCFAs concentration in the intestinal lumen varies between 60 and $150 \mathrm{mmol} / \mathrm{kg}$, and their daily production in the large intestine of a healthy individual is 300-400 mmol; assuming a daily production of $9 \mathrm{~L}$ of the intestinal content, among SCFAs the physiological concentration range of the C- 4 fatty acid butyrate is $9-90 \mathrm{mmol} /$ day $(1-10 \mathrm{mmol} / \mathrm{L})$ [19]. This daily demand of butyrate (1-10 g/day) should be covered by the fermentation processes of RS and food fibers, but the insufficient intake of these foodstuffs in Western population could represent the link of the rapid growing of many chronic non transmissible conditions. Butyrate is a functionally extremely versatile molecule potentially useful for the prevention and treatment of several metabolic diseases. Here, we review several mechanisms that contribute to explain the role of butyrate in this context.

\section{Butyrate}

\subsection{Factors that Promote/Inhibit Butyrate Production}

The importance of SCFAs for human health has been demonstrated in many studies. The production of these acids in sufficient quantities by the GM is essential for the health homeostasis and well-being of the host [20]. However, the production of these metabolites depends on the GM's structure, whose function/composition is highly variable and significantly influenced by various factors, such as age, genetics, lifestyle and environment [21]. Hygiene and the use of antibiotics, together with the "Westernization" of lifestyles are associated with an imbalanced GM, or dysbiosis, which may lead to suppression of butyrate production [22-24]. Voluptuous habits like smoking or drinking alcohol could also drive to a reduction of butyrate production, due to a decrease of its fermenting bacteria producers in the GM $[25,26]$. Different dietary patterns, in particular of macronutrients and micronutrients diet composition and the nutritional sources of foods, contribute to GM remodeling. Among macronutrients, $\mathrm{CHO}$ play the most crucial role in shaping the bacterial community and their effects on GM have been the most described; according to their degree of polymerization (DP), they can be divided into sugars (DP 1-2), oligosaccharides (short-chain carbohydrates) (DP 3-9) and polysaccharides (DP > or $=10$ ) and based on their capability to be enzymatically degraded in the small intestine, in digestible and non-digestible CHO [27]. It has been evidenced that simple sugars (e.g., sucrose, fructose) cause rapid GM deregulation and hence metabolic dysfunction in the host [28,29]; moreover contrary to popular belief, non-caloric artificial sweeteners (e.g., saccharin, sucralose, aspartame, cyclamate, neotame and acesulfame potassium), which are promoted as substitutes of foods and drinks rich in sugars calories, may be considered unhealthy for reporting both dysbiosis and disruption of metabolic homeostasis, such as glucose intolerance in a GM-dependent manner [30]. While, non-digestible $\mathrm{CHO}$, specifically fiber and RS are beneficial for GM composition; in particular, fiber is a good source of MACs, necessary substrate for butyrate production as reported above, moreover a recent systematic review and meta-analysis found that dietary fiber beneficially modulates the metabolic outputs of the GM, likely due to cross-feeding interactions between butyrate producers and Bifidobacterium and Lactobacillus species [31]. Among macronutrients, proteins represent an essential source of daily energy for human diet. High dietary protein intake leads to a disproportionate decrease in faecal butyrate with a markedly decline in butyrate-producing Roseburia/ Eubacterium rectale group of bacteria populations [32]. Several dietary patterns, including Western, gluten-free, omnivore, vegetarian, vegan, and Mediterranean, have been studied for their ability to modulate the GM; among these a high adherence to the Mediterranean diet (MD) was associated with a beneficial microbiome-related metabolomic profile (high 
Prevotella and certain fiber-degrading Firmicutes profiles, high SCFAs production) [33]. The increased intestinal SCFAs level induced by MD diet is determined by high consumption of vegetables, fruits and legumes, which are rich sources of complex and insoluble fiber, the major substrates for microbial production of SCFAs. These foodstuffs are typical of vegan/vegetarian diet, in which SCFAs production is usually increased; farther, typical constituents of plant foods are polyphenols, a broad group of substances (such as catechins, flavonols, flavones, anthocyanins, phenolic acids) with well-described antioxidant properties. Previous studies have shown that polyphenols have a beneficial effect on GM by increasing the abundance of Bifidobacterium and Lactobacillus and elevating the production of SCFAs [13,34]. Habitual dietary pattern can shape the structure and function of the GM, influencing the availability of the GM metabolite butyrate. In fact, a Western diet quickly modifies the composition and metabolic activity of the GM, as demonstrated in the animal model by Carmody and co-workers. In fact, they demonstrated that the consumption of a high-fat and high-sugar diet altered the GM in a linear dose response way, taking an average time of 3.5 days [35]. Although it has previously been suggested that the human GM under normal conditions is relatively stable, other studies have shown that even in adults the microbiota composition can be highly variable and changes over the course of a day [36] or weeks [37]. Behavioral factors, including timing of eating and overnight-fast duration, were also predictive of bacterial abundances. Kaczmarek and co-workers showed that SCFAs concentrations decrease over the course of the day, in particular butyrate, because the amount of Roseburia and Eubacterium, bacteria producing butyrate, decreased throughout the day [36]. Previously, it has been demonstrated that butyrate has a rhythmically behaviour in murine models [38]. However, only few human studies have primarily emphasized changes in gut microbial diversity (for example, Bacteroidetes-to-Firmicutes ratio) following dietary intake of RS or other fermentable CHO [39-41]. Some interesting works have underlined that rapid changes in microbial metabolic activity and diversity related to the protein, lipid and dietary fibers content of the diet [42,43]. In particular, David and co-workers have also observed significant positive correlations between clusters, such as Roseburia, E. rectale, and F. Prausnitzii that are butyrate producers, and the results of $\mathrm{CHO}$ fermentation [42]. In Figure 1 are represented the factors that promote/inhibit butyrate production through a positive or negative modulation of the GM.

\subsection{Dietary Sources of Butyrate}

Dietary sources by which bacterial fermentation produced butyrate are non-digestible $\mathrm{CHO}$, including dietary fibers, resistant starch (RS) and complexes of amylose and/or amylopectin [44-46]. RS naturally occurs in foods such as cooked and cooled potatoes, raw bananas, legumes, plant material and partly milled seeds [47]. RS can also be incorporated into breakfast cereals, tortillas, breads and corn (maize) through manufacturing techniques as well as fortification $[47,48]$. Farther, albeit to a small extent, butyrate is also formed as fermentation product of peptides and amino acids of protein foods: although the numbers of amino acid-fermenting bacteria have been estimated to constitute less than $1 \%$ of the large intestinal microbiota, SCFAs represent their catabolism metabolites [17,49]. As such, butyrate occurs in dairy products in considerable amounts, e.g., butter $(\sim 3 \mathrm{~g} / 100 \mathrm{~g})$, cheese (especially goat's cheese $(\sim 1-1.8 \mathrm{~g} / 100 \mathrm{~g})$, parmesan $(\sim 1.5 \mathrm{~g} / 100 \mathrm{~g})$, whole cow's milk $(\sim 0.1 \mathrm{~g} / 100 \mathrm{~g})$, due to microbial anaerobic fermentation of fibers, including cellulose, in the ruminant gut [50]. Human milk (HM) has also been examined as a potential source of butyrate for infants, contributing to their colonic microbiota modulation [51-53]. Evidences support the hypothesis that HM butyrate could be or derive from the maternal enteromammary circle or could be produced by the mammalian gland breast milk microbiome: this hypothesis is supported by recent observations demonstrating the presence of potential butyrate-producer bugs [53-58]; moreover, a potential pathway in HM butyrate production could derive by $\mathrm{HM}$ oligosaccharides (HMOs) metabolization by selected bacteria in the breast $[56,59]$. 


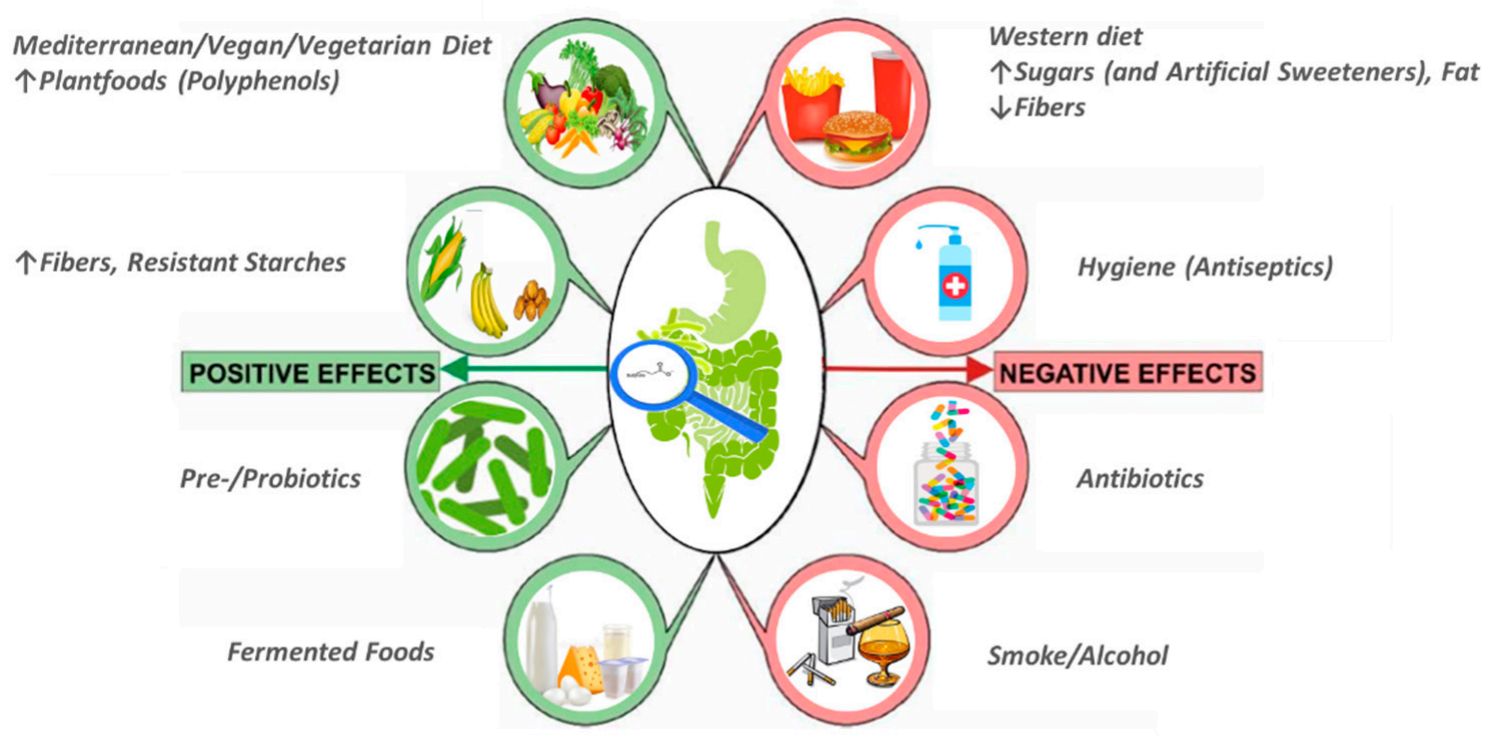

Figure 1. Factors that promote/inhibit butyrate production through a positive or negative modulation of the gut microbiota (GM). Among negative factors, hygiene and the use of antibiotics, together with the "Westernization" of lifestyles (high consumption of fats and sugars, sedentary lifestyle) are associated with an imbalanced intestinal microbiota, or dysbiosis, which may lead to suppression of GM fermentation and butyrate production. Farther, voluptuous habits like smoking or drinking alcohol could also drive in a reduction of butyrate production, due to a decrease of its fermenting bacteria producers in the GM. Within the factors that positively affect the production of butyrate there are dietary patterns characterized by a high consumption of plant foods (Mediterranean, vegan/vegetarian diet), source of fiber, resistant starch and polyphenols, necessary substrates for butyrate production. Moreover, among positive modulator arise nutritional supplementation with prebiotics (that can serve as the substrates for bacterial fermentation in the colon to generate butyrate) and/or probiotics, live cultures of specific strains of bacteria that colonize the intestinal tract to promote generation of butyrate (food sources of probiotics are yogurt, fermented cheeses etc.).

\subsection{Endogenous Production of Butyrate}

There are two pathways for the formation of butyrate from butyryl-CoA, (1) the butyryl-CoA:acetate CoA-transferase (butCoAT) pathway, which relies on the presence of exogenous acetate, and (2) the phosphor-transbutyrylase/butyrate kinase (buk) pathway [17]. Butyrate production is widely distributed among phylogenetically diverse human colonic Gram-positive Firmicutes [60]. Although numerous bacterial strains have been analyzed for their butyrate-producing capacities, Faecalibacterium prausnitzii (a member of Clostridium cluster IV) and Eubacterium rectale/Roseburia (Clostridium cluster XIVa) have currently received the most attention, as they constitute $5-10 \%$ of total bacteria in fecal samples collected from healthy adults [60]. In addition to the colonization of the colon by butyrogenic bacteria, it has been proposed that cross-feeding interactions between Bifidobacterial strains and F. prausnitzii may ultimately enhance butyrate production [61]. Through the production of butyrate, GM could modulate also neurodevelopmental health/disease. The importance of the gut-brain axis has been widely described and a growing body of evidence highlights a role for alterations in the GM in the pathophysiology of many neurologic and neuropsychiatric diseases, including autism spectrum disorder (ASD). Hua and co-workers reported a significantly reduction in the abundances of butyrate-producing bacteria Faecalibacterium and Agathobacter in ASD children [62]. To further emphasize this link recent work has shown that GM alterations leads to have a significant impact on amygdala development in infancy, modulating the development of the frontal cortex and other brain regions [63]. 


\subsection{Physiological Intestinal, Portal and Systemic Butyrate Concentrations}

The $20 \%$ of total SCFAs produced in the colon consists of butyrate, whose production is $14,700-24,400 \mu \mathrm{mol}$ per $\mathrm{kg}$ of luminal content in the colon, and it represents only the $8 \%$ of the total SCFAs in portal vein $(15-30 \mu \mathrm{mol} / \mathrm{L})$ [64]. Compared to colonic levels, human plasma concentration of butyrate is $<10 \mu \mathrm{M}$ [65-69], because butyrate is the preferred energy source for colonocytes and the majority of absorbed may already be consumed by the colonic mucosa. Bloemen and coworkers showed that the release of butyrate from the liver is not significantly different from zero, suggesting a splanchnic (gut + liver) extraction of $\sim 100 \%$ [70]; more recently, the quantification of the percentages of acetate, propionate and butyrate originating from the colon that reached the systemic circulation was evaluated in healthy subjects through the direct stable isotope approach that quantified butyrate systemic availability (2\%) and its splanchnic extraction that was of $98 \%$ [71].

\subsection{Butyrate Absorption}

All SCFAs are rapidly and almost completely absorbed by the enterocytes and delivered through the portal vein into the liver and systemic circulation. Likely the other SCFAs, butyrate is readily absorbed through a non-ionic diffusion across the apical mem-brane of colonocytes for its hydrophobicity and low molecular weight [72,73]. However, since $10 \%$ of SCFAs are revealed in the feces, there may be another mechanism for their uptake [74]. It has been speculated that sodium-coupled monocarboxylate transporter 1 (SCMT1) is able to sequester SCFAs within colonocytes utilizing the colonic $\mathrm{Na}^{+}$concentration gradient [74-76], but the solute carrier family 5 member 8 (SLC5A8) is the primary transporter of butyrate across the apical membrane of the colonocytes. SMCT1 has a preference for butyrate and transports propionate and acetate at a slower rate, although it is probably still the main transporter for them [77,78]. It may also be the crosstalk node between the microbiome and the host [72,76]. It has been proposed that proton-coupled monocarboxylate transportation and SCFA-bicarbonate antiporters could be a viable mechanism for SCFAs uptake as well as regulators of lumen $\mathrm{pH}$ [79-82]. The overlap among SCFAs in absorption is not surprising, since butyrate metabolism satisfies $\sim 70 \%$ of colonocytes energy requirements $[71,72,83]$.

\subsection{Cellular Signaling Pathways of Butyrate}

Butyrate is the ligand for metabolite-sensing G-protein coupled receptors (GPCRs), such as GPR43, GPR41 and GPR109A [84-87]. GPR43 and GPR41 are known as free fatty acid receptors 2 (FFAR2) and 3 (FFAR3), respectively [85,88]. GRP41/FFAR3 receptors are expressed in peripheral nerves, enteroendocrine $L$ and $K$ cells, white adipocytes, pancreatic $\beta$-cells, thymus and myeloid dendritic cells; GRP43/FFAR2 receptors are expressed in white adipocytes, enteroendocrine $L$ cells, intestinal epithelial cells, pancreatic $\beta$ - cells, and several immune system cells such as colonic T-regulatory (Treg) cells, M2 macrophages, neutrophils, eosinophils and mast cells [89]. In particular, FFAR2 can activate both the Gi/o and the Gq pathways, while GPR109A and FFAR3 can only utilize the Gi/o pathway $[88,90]$. For the Gq pathway, DAG and IP3 may also activate protein kinase C (PKC) to stimulate the downstream activities of the extracellular signal-regulated kinase $\frac{1}{2}$ (ERK-1/2) and c-Jun Nterminal kinase (JNK) pathways [91]. FFAR2 and FFAR3 activation regulates inflammatory pathways such as that are important in determining gut health, such as mitogen-activated protein kinase (MAPK) signaling [92,93]. Butyrate GPCR activation in the gut induces the secretion of endocrine hormones glucagon-like peptide 1 (GLP-1) and peptide YY (PYY) $[87,94,95]$. It is largely known that GLP-1 increase insulin secretion and that FFAR2 knockout (KO) mice have decreased serum insulin levels [94], while PYY influences energy intake and expenditure at hypothalamus and brainstem levels and FFAR3 KO mice have very low PYY expression [96-98]. In particular, butyrate-induced the up regulation of GLP-1 and PYY may be important in preventing or treating obesity and insulin resistance. On the contrary, GPR109A increase glucose uptake and may contribute to hyperglycemia, obesity and insulin resistance [99,100]; it has also been observed that GPR109A has an 
age-dependent increased expression in the jejunum of diabetic mice. Butyrate is also a histone deacetylase inhibitor (HDACi), targeting class I and II HDACs [101,102], so it may regulate epithelial cell gene expression through epigenetic mechanism involving chromatin remodeling as well as through targeting and regulation of non-histone proteins [101]. As HDAC inhibitor, butyrate may have a potential in the therapy of these conditions improving synaptic plasticity and cognition deficits. Recently has been demonstrated that butyrate has positive effects on social behavior in an ASD mouse model [103], and in general, butyrate can enhance mitochondrial function in the context of physiological stress and/or mitochondrial dysfunction [104]. In particular, Berding and Donovan have underlined that GM composition of children with ASD could vary over time and that diet might play an important role in determining stability of GM in this population [105]. Because of the pleiotropic intracellular signaling effects of butyrate, the physiologic effects of butyrate are multivariate, with outcomes dependent upon tissue type, dosage and time effects. It has been reported that butyrate is able to influence the expression of colonic tight junction (TJ) proteins including claudin-2, occludin, cingulin, and zonula occludens proteins (ZO-1, ZO-2) [106]. Butyrate also facilitated the association between transcription factors and the claudin-1 promoter [107], increased AMP-activated protein kinase (AMPK) activity [108] and reduced bacterial translocation [109]. It was reported that butyrate could also influence the function of the intestinal barrier activating peroxisome proliferator-activated receptor $\gamma($ PPAR- $\gamma)[108,110]$ and modifying transporters expression in vivo and in vitro [111], including MCT1 and MCT4 [112]. Several studies have reported that PPAR- $\gamma$ is also involved in colon cell differentiation and colon cancer $[113,114]$. Byndloss and co-workers have found out that a depletion of butyrate-producing microbes by antibiotic treatment reduced epithelial signaling through the intracellular butyrate sensor PPAR- $\gamma$ [115]. Nitrate levels increased in the colonic lumen because epithelial expression of Nos2, the gene encoding inducible nitric oxide synthase (iNOS), was elevated in the absence of PPAR- $\gamma$-signaling. Microbiota-induced PPAR- $\gamma$-signaling also limits the luminal bioavailability of oxygen by driving the energy metabolism of colonocytes towards $\beta$-oxidation. Therefore, microbiota-activated PPAR- $\gamma$-signaling is a homeostatic pathway that prevents a dysbiotic expansion of potentially pathogenic Escherichia and Salmonella by reducing the bioavailability of respiratory electron acceptors to Enterobacteriaceae in the colonic lumen. Furthermore, butyrate has anti-inflammatory effects that result from inhibition of activation of the transcription factor $\mathrm{\kappa B}(\mathrm{NF}-\mathrm{kB})$, and consequent reduced formation of proinflammatory cytokines $[116,117]$. Depending on its concentration, butyrate can inhibit growth or promote differentiation of human cells in tissue culture. It can also induce apoptosis in tumor cells, while also acting as atrophic factor for cells in intact tissues [118]. All these interactions here reported have important consequences for the health of the colonic epithelium and for the host homeostasis. In Figure 2 there is a schematic illustration of the direct and indirect effects of butyrate on the regulation of host metabolic functions. 


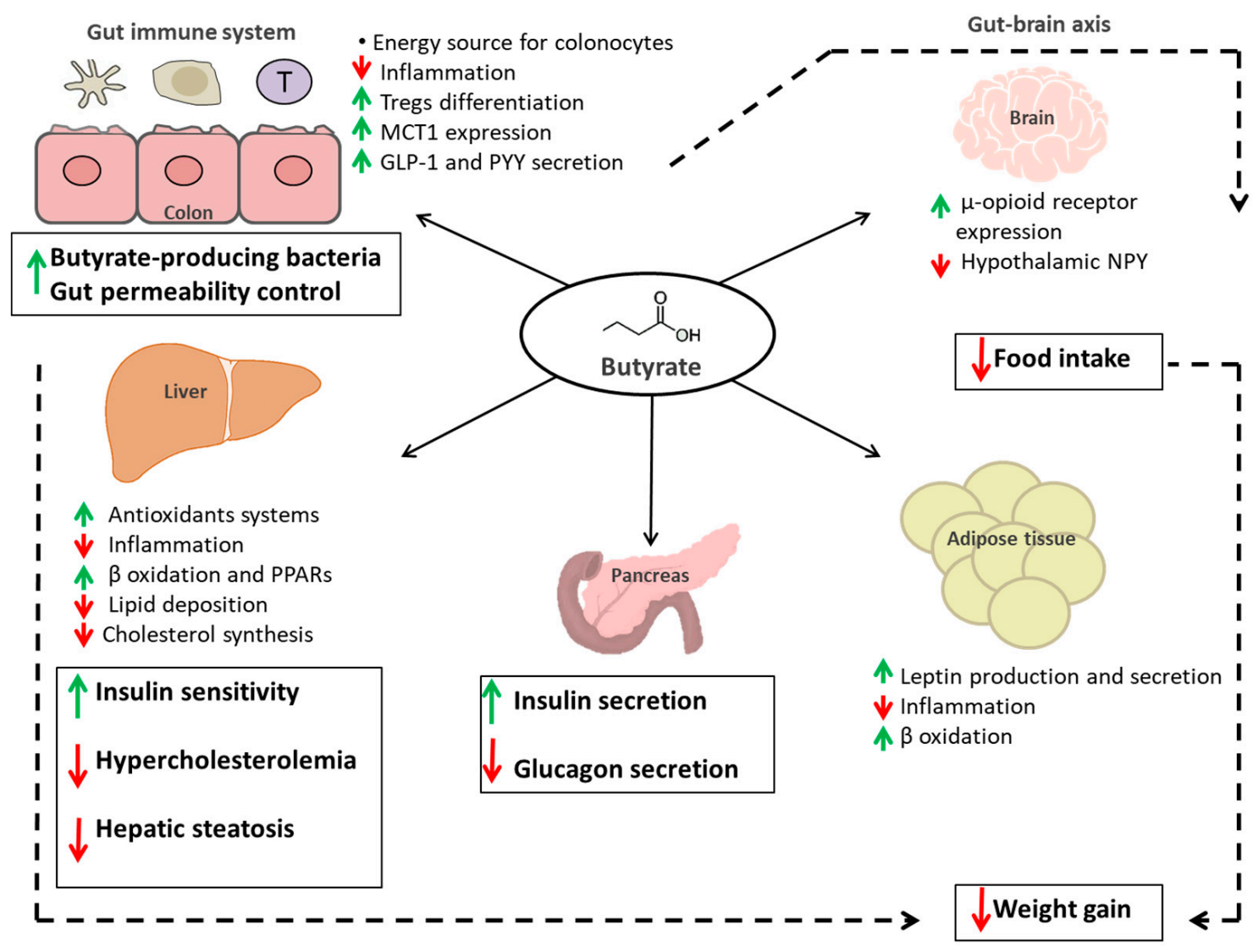

Figure 2. Schematic illustration of the direct (continuous black arrow) and indirect (dotted black arrow) effects of butyrate on the regulation of host metabolic functions. Butyrate positive effects are indicated with a green arrow, negative ones are indicated with red arrows. Abbreviations: Tregs: T regulatory cells; MCT1: Monocarboxylate transporter 1; GLP-1: Glucagon-like peptide 1; PYY: Peptide YY; NPY: Neuropeptide Y; PPARs: Peroxisome proliferator-activated receptors.

\section{Butyrate as a Regulator of Body Weight}

\subsection{Butyrate and Energy Expenditure}

Modulating the energy intake-expenditure balance in the body is one of the best strategies for obesity therapy. Butyrate could act as a regulator of body weight: a reasonable speculation is that it acts on components of the energy balance, promoting energy expenditure and/or reducing energy intake. Butyrate supplementation was found to have multiple metabolic benefits, including prevention of high-fat diet (HFD)-induced obesity and obesity-associated disorders in the animal model [119-124]. In addition to its preventive actions in diet-induced disease models, butyrate is also effective in treating obesity through the promotion of energy expenditure and the induction of mitochondrial function: the mechanism of butyrate action for obesity is related to the activation of AMPK, increasing ATP consumption, and the induction of PGC- $1 \alpha$ activity, the molecular mechanism by which butyrate stimulates mitochondrial function in association with up-regulated expression of genes involved in lipolysis and fatty acid $\beta$-oxidation [125-127]. Adipose tissue is an endocrine organ which constitutes the largest energy reservoir in the body and plays an important role in energy homeostasis. Thus, increasing fat mobilization in adipose tissue is an attractive potential strategy for the management and treatment of obesity. Butyrate-mediated regulation of thermogenesis and energy homeostasis was also demonstrated in a recent study performed in mice: it promotes thermogenesis in brown adipose tissue (BAT) through the activation of lysine specific demethylase (LSD1), a histone demethylase, important regulator of thermogenesis [128]. Farther, $\beta$-adrenergic receptors that are largely expressed in adipose tissue, play a fundamental role in lipolysis. Another speculation by which butyrate could induce fat burning is $\beta 3$-adrenergic receptors activa- 
tion in mice white adipose tissue, which may encourage potential anti-obesity application of butyrate in humans [129].

\subsection{Butyrate and Energy Intake}

Evidence suggest that butyrate inhibit weight gain via suppressing food intake: $\mathrm{Li}$ and coworkers showed that oral administration of butyrate in mice induces satiety and reduces cumulative food intake, suppressing the activity of orexigenic neurons that express neuropeptide $\mathrm{Y}$ in the hypothalamus indicating a mechanism involving the gut-brain neural circuit [130]. In addition, the hypophagic effect of butyrate can be explained through the increase of anorexigenic gut hormones that directly act on the hypothalamus to regulate satiety signaling; in fact, several animal studies showed that oral butyrate has the capacity to evoke an anorectic response increasing plasma levels of GLP-1, glucosedependent insulinotropic polypeptide (GIP) and PYY [94,131]. In a randomized clinical trial, the colonic infusion of butyrate as SCFAs mixtures increased fat oxidation and fasting and postprandial plasma PYY concentrations in overweight/obese humans [132]. In the context of human studies, another interesting one conducted in a group of obese volunteers with metabolic syndrome showed that the oral supplementation with $4 \mathrm{~g}$ of sodium butyrate per day decreased oxLDL-induced trained immunity for LPS-induced IL-6 responses and Pam3CSK4-induced TNF- $\alpha$ response, showing a positive anti-inflammatory and immunomodulatory effect and possibly slowing down the process of vascular wall inflammation and the progression of atherosclerosis, one of the metabolic complications caused by obesity [133]. Butyrate also acts through the regulation of the opioidergic system and therefore with subjective pleasure and dysphoria that guide food intake. Especially via reward regulation, alterations in the opioidergic system are intimately associated with food intake dysregulation in obesity. Decrease in $\mu$-opioid receptor levels have been proposed to drive food intake in obese individuals, but butyrate epigenetically upregulates the $\mu$-opioid receptor whose activation is classically associated with reward [134]. Based on the available data butyrate can be seen as a novel strategy to improve long-term energy homeostasis.

\section{Butyrate and Liver}

Obesity is closely related with liver metabolism disorders, such as non-alcoholic fatty liver disease (NAFLD), a hepatic lipid-related metabolic disorder that represents a spectrum of liver derangements starting from benign steatosis that progresses to nonalcoholic steatohepatitis (NASH) characterized by insulin resistance, liver inflammation and fibro-sis [135].

\subsection{Butyrate and Lipids Metabolism Impairment}

An impairment of lipidemia appears to have a central role in the pathogenesis and progression of the metabolic disorders associated with obesity. Butyrate could regulate lipid metabolism in the liver and intestine and several findings showed that it exerts beneficial effects on liver diseases. It is able to downregulate the expression of nine key genes involved in the intestinal cholesterol biosynthesis pathway and thereby it may inhibit hypercholesterolemia $[136,137]$. Cholesterol homeostasis is a dynamic balance between biosynthesis, uptake, export and esterification: when cholesterol is in surplus it is esterified and stored as reservoir in cytosolic lipid droplets or released as a major constituent of plasma lipoproteins, including chylomicrons, VLDLs, LDLs and HDLs [138]. Butyrate modulates the cellular events governing the assembly and delivery of lipoproteins as demonstrated in a decrease secretion of chylomicrons and VLDLs in butyrate-treated Caco-2 cells [139]. The reverse cholesterol transport (RCT) has a role in atherosclerosis development, promoting the movement of cholesterol from the peripheral tissues to the liver for reuse or for the final elimination into the bile and retarding the plaque progression. Butyrate may accelerate RCT and thus preventing atherosclerosis development, by activating ATP-binding cassette sub-family A member 1 (ABCA1) expression, that promotes cholesterol efflux to lipid-free/poor apolipoprotein A-I, both in liver and in plaque (pe- 
ripheral macrophages), via a specificity protein 1 (Sp1) pathway, as shown in HFD-induced Apolipoprotein E deficiency (ApoE-/-) mice model [140]. Scavenger receptor class B type I (SR-BI), the first molecularly well-defined HDL receptor in mice, and its human homologue CLA-1 (CD36 and Lysosomal integral membrane protein-II Analogous-1) plays a pivotal role both in the initial (cholesterol efflux and removal from the artery wall) and final (selective HDL-cholesterol uptake in the liver) phase of RCT; it has previously shown that butyrate might enhance the transcriptional activity of SR-BI/CLA-1 expression in human hepatoma HepG2 cells, facilitating RCT with an antiatherogenic activity [141].

\subsection{Butyrate and Liver Disorders}

Butyrate administration ameliorates hepatic steatosis induced by HFD in mice, through a reduction in intrahepatic lipid accumulation (triglycerides and phospholipids content) and reduction of liver weight $[118,129,142]$. In-depth mechanistic investigation focused on the liver showed that hepatic mitochondria are the main target of the beneficial effect of butyrate in reverting fat accumulation in diet-induced obesity [143]. Hepatic mitochondrial dysfunction is a key pathway for the alteration of fat oxidation, reactive oxy-gen species production, oxidative stress, and the progression of NAFLD [144]. Sun and coworkers showed that butyrate up-regulated hepatic expression of peroxisome proliferator-activated receptor $\alpha(\operatorname{PPAR} \alpha)$, essential regulator for mitochondrial fatty acid oxidation, alleviating HFD-induced NAFLD in rats, through the activation of $\beta$-oxidation and inflammation suppression [145]. Butyrate is able to attenuate inflammatory mediators re-leasing in liver [146]; this effect indicated that butyrate promotes the maintenance of liver homeostasis, with the decrease of many pro-inflammatory factors (MCP-1, TNF- $\alpha$, IL-1, IL-2, IL-6, IFN- $\gamma$ ) and the increase of anti-inflammatory ones (IL-4, IL-10), that could occur through the immunoregulation of via inhibiting histone acetylation enzymes or GPCRs pathway, as shown in HFD-induced steatohepatitis mice model [147]. Through the activation of GPCR (GLP-1R), GLP-1 exerts its effects in lipid metabolism, protecting hepatocytes against steatosis [148,149]: HFD and lipotoxicity, typical of obesity, induce the loss of GLP-1 responsiveness, but butyrate has the capability to upregulate hepatic GLP-1R expression, with a decrease in fatty acid synthesis lead by the involvement of (AMP)-activated protein kinase/AcetylCoA carboxylase (AMPK/ACC) signaling [150,151].

\section{Butyrate and Type 2 Diabetes}

The worldwide occurrence of diabetes (both type-1 and type-2) is predicted to rise to 629 million by 2045 [152]. Obesity is a predisposing element in the development of type 2 diabetes mellitus (T2DM) which accounts for 90-95\% of all diabetes cases [153]. The primary induction driver of numerous life-threatening complications and comorbidities is the dysregulation of glucose metabolism (fasting and postprandial hyperglycemia), with many deleterious downstream effects such as chronic inflammation, cardiovascular dis-eases, gut microbial dysbiosis, with an enhancement in opportunistic pathogens and a reduction of many butyrate-producing bacteria [154]. However, this glycemic alteration can be followed to progressive impairments in insulin sensitivity (i.e., insulin resistance) and a corresponding failure of pancreatic islets to maintain appropriate insulin output to compensate for the decline in insulin sensitivity (i.e., islet failure) [155]. Islets are known to express the butyrate receptors GPR41 and 43, indicating that it might be involved in islet-cell metabolism and function [156-159], as demonstrated by the effects of butyrate pre-incubation in improving diabetes-induced histological alteration of islet and functional damage $[160,161]$. There has been revealed an anti-diabetogenic effect of butyrate in animal models of T2DM, which was related to its action as HDAC inhibitor [162]. HDAC inhibition ameliorates hyperglycemia by controlling the expression of glucose-6-phosphate and the subsequent gluconeogenesis [163]. 


\section{Butyrate and GLP-1 Secretion}

Butyrate is able to stimulate the release of GLP-1 from intestinal L-cells as shown both in cell culture system and animal model $[164,165]$. GLP-1 has the ability to reduce apoptosis and to induce pancreatic $\beta$-cells neogenesis and regeneration, as well as to induce insulin synthesis and secretion; GLP- 1 activates the GLP-1R GPCR in $\beta$ cells, resulting in production of cAMP, which in turn leads to an increase in glucose-stimulated insulin secretion [166]. Preclinical data are also confirmed by a randomized, double blind, clinical placebo control trial on type 2 diabetic adults, where was shown a significant increase in postprandial GLP-1 concentration after butyrate supplementation and a decreasing trend was observed for homeostatic model assessment of insulin resistance (HOMA-IR) indices [167]. Interestingly, oral butyrate treatment beneficially affects glucose metabolism in lean subjects, who benefited from an improvement in both peripheral and hepatic insulin sensitivity at a dosage intake of $4 \mathrm{~g}$ of sodium butyrate daily for 4 weeks [65]. At this juncture, an interesting speculation may be to develop butyrate-based therapies for diabetic or pre-diabetic patients to exploit its beneficial effects in the context of obesityrelated glucose metabolism impairment.

\section{Conclusions}

Butyrate is a functionally extremely versatile molecule produced by human GM. Host metabolism and immune function are critically regulated by butyrate. This implicates butyrate as a key mediator of host-microbe crosstalk, as well for its ability to regulate different metabolic pathways at the same time. The Table 1 summarizes main preclinical and clinical data on the butyrate's effects in the context of obesity and related metabolic diseases.

Table 1. Main preclinical and clinical evidences on the protective role of butyrate against obesity and obesity-related diseases.

\begin{tabular}{|c|c|c|}
\hline Effect & Preclinical & Clinical \\
\hline$\uparrow$ fat oxidation; $\uparrow$ fasting and postprandial plasma PYY concentrations & & [118] \\
\hline $\begin{array}{l}\text { Prevention of HFD-induced obesity, improvements in obesity-related lipid } \\
\text { accumulation and low-grade chronic inflammation ( } \downarrow \text { serum LPS concentrations) }\end{array}$ & [106] & \\
\hline Recovering HFD-induced changes in body weight, adiposity, liver pathology & {$[107,108]$} & \\
\hline $\begin{array}{l}\text { Prevention of HFD-induced increase in body weight and adiposity; liver inflammation } \\
\text { and damage, steatosis, impairment of glucose homeostasis and the onset of IR }\end{array}$ & {$[108,109]$} & \\
\hline $\begin{array}{l}\text { Promotion of energy expenditure and mitochondrial function induction (AMPK } \\
\text { activation; induction of PGC- } 1 \alpha \text { activity; } \uparrow \text { expression of genes involved in lipolysis } \\
\text { and fatty acid } \beta \text {-oxidation; alleviating diet-induced obesity through activation of } \\
\text { AR } \beta 3 \text {-mediated lipolysis in WAT }\end{array}$ & {$[113,115]$} & \\
\hline $\begin{array}{l}\text { Shifting metabolism in adipose and liver tissue from lipogenesis to fatty acid } \\
\text { oxidation (downregulation of PPAR } \gamma \text { activating an UCP2-AMPK/ACC network) }\end{array}$ & [112] & \\
\hline $\begin{array}{l}\text { Alleviating HFD-induced obesity (through activation of adiponectin-mediated } \\
\text { pathway and stimulation of mitochondrial function in the skeletal muscle) }\end{array}$ & [111] & \\
\hline Induction of thermogenesis in BAT and scWAT (LSD1 activation) & [114] & \\
\hline $\begin{array}{c}\text { Action on the gut-brain neural circuit to improve energy metabolism via } \downarrow \text { energy } \\
\text { intake and } \uparrow \text { fat oxidation by activating BAT }\end{array}$ & [116] & \\
\hline $\begin{array}{l}\text { Gut hormone release regulation ( } \uparrow \text { GLP- } 1, \text { GIP), } \downarrow \text { food intake, diet-induced obesity } \\
\text { protection }\end{array}$ & {$[83,117,150,151]$} & \\
\hline $\begin{array}{l}\downarrow \text { oxLDL-induced trained immunity for LPS-induced IL-6 responses and } \\
\qquad \text { Pam3CSK4-induced TNF- } \alpha \text { responses }\end{array}$ & & [119] \\
\hline $\begin{array}{l}\downarrow \text { expression of nine key genes involved in the intestinal cholesterol biosynthesis } \\
\text { pathway; hypercholesterolemia inhibition }\end{array}$ & {$[122,123]$} & \\
\hline$\downarrow$ secretion of chylomicrons and VLDLs & [125] & \\
\hline
\end{tabular}


Table 1. Cont.

\begin{tabular}{|c|c|c|}
\hline Effect & Preclinical & Clinical \\
\hline $\begin{array}{l}\text { Ameliorating HFD-induced atherosclerosis (via ABCA1-mediated cholesterol efflux in } \\
\text { macrophages) }\end{array}$ & [126] & \\
\hline $\begin{array}{l}\text { Facilitating reverse cholesterol transport with an antiatherogenic activity } \\
\text { ( } \uparrow \text { SR-BI/CLA-1 expression) }\end{array}$ & [127] & \\
\hline $\begin{array}{l}\text { Suppression of HFD-induced liver weight gain and hepatic TGs accumulation; } \\
\text { improvement of hepatic metabolic conditions via FFAR3 }\end{array}$ & [128] & \\
\hline $\begin{array}{l}\text { Ameliorating HFD-induced NAFLD through PPAR } \alpha \text { - mediated activation of fatty } \\
\text { acid } \beta \text { oxidation and inflammation suppression }(\downarrow N F-\kappa B)\end{array}$ & [131] & \\
\hline Promotion of liver homeostasis ( $\downarrow$ pro-inflammatory and $\uparrow$ anti-inflammatory factors) & {$[132,133]$} & \\
\hline$\uparrow$ fatty acid oxidation, $\downarrow$ fatty acid synthesis (via AMPK/ACC pathway) & {$[129,137]$} & \\
\hline Anti-diabetogenic effect ( $\uparrow$ GLP-1 secretion; $\uparrow$ insulin sensitivity; & {$[148,150,151]$} & {$[54,153]$} \\
\hline$\uparrow$ phosphorylation of insulin receptor; $\uparrow$ GLUT2 expression) & [129] & \\
\hline$\uparrow$ diabetes-induced histological alteration of pancreatic islet and functional damage & {$[146,147]$} & \\
\hline
\end{tabular}

PYY: peptide YY; HFD: high fat diet; LPS: lipopolysaccharides; IR: insulin resistance; AMPK: adenosine $5^{\prime}$-monophosphate-activated protein kinase; PGC- $1 \alpha$ : peroxisome proliferator-activated receptor (PPAR)- $\gamma$ coactivator (PGC)- $1 \alpha$; AR $\beta 3$ : $\beta 3$-adrenergic receptor; WAT: white adipose tissue; PPAR $\gamma$ : peroxisome proliferator-activated receptor- $\gamma$; UCP2: mitochondrial uncoupling protein 2; AMPK/ACC: AMP-activated protein kinases/acetyl coenzyme A carboxylase; BAT: brown adipose tissue; scWAT: subcutaneous white adipose tissue; LSD1: lysine specific demethylase; GLP-1: glucagon-like peptide 1; GIP: glucose-dependent insulinotropic peptide; oxLDL: oxidized low-density lipoprotein; IL-6: interleukin 6; TNF- $\alpha$ : tumor necrosis factor $\alpha$; VLDLs: very low-density lipoproteins; ABCA1: ATP-binding cassette sub-family A member 1; SR-BI: scavenger receptor class B type I; CLA-1: CD36 and lysosomal integral membrane protein-II analogous-1; TGs: triglycerides; FFAR3: free fatty acids receptors 3; NAFLD: non-alcoholic fatty liver disease; PPAR $\alpha$ : peroxisome proliferator-activated receptor $\alpha$; NF- $\mathrm{BB}$ : nuclear factor $\mathrm{\kappa B}$; GLUT2: glucose transporter 2 .

Increasing endogenous butyrate production could be a valuable strategy in the prevention of obesity and related metabolic diseases, but also increasing exogenous intake through butyrate supplements. Most likely, the causative lack of randomized controlled trials proving the efficacy of butyrate in these metabolic disorders is mainly due to the poor palatability of the actual butyrate preparations available on the market. Nevertheless, there is an urgent need for products that mask the unpleasant organoleptic properties of butyrate, in order to facilitate clinical studies in children and in adult patients.

Author Contributions: S.C. and C.A. contributed to the conception and design of the paper, performed the review literature search and wrote the first draft. R.B.C. contributed to the conception and design of the paper and reviewed the draft. A.C. contributed to the conception of the paper and reviewed the draft. All authors have read and agreed to the published version of the manuscript.

Funding: This research received no external funding.

Data Availability Statement: No new data were created or analyzed in this study. Data sharing is not applicable to this article.

Acknowledgments: We thank all researchers involved at our Center in the investigation on innovative strategies against obesity.

Conflicts of Interest: The authors declare no conflict of interest.

\section{References}

1. World Health Organization. Obesity and Overweight. Available online: http://www.who.int/mediacentre/factsheets/fs311/en/ (accessed on 27 November 2020).

2. Schetz, M.; De Jong, A.; Deane, A.M.; Druml, W.; Hemelaar, P.; Pelosi, P.; Pickkers, P.; Reintam-Blaser, A.; Roberts, J.; Sakr, Y.; et al. Obesity in the critically ill: A narrative review. Intensive Care Med. 2019, 45, 757-769. [CrossRef] [PubMed]

3. Rohde, K.; Keller, M.; la CourPoulsen, L.; Blüher, M.; Kovacs, P.; Böttcher, Y. Genetics and epigenetics in obesity. Metabolism 2019, 92, 37-50. [CrossRef] [PubMed]

4. Blüher, M. Obesity: Global epidemiology and pathogenesis. Nat. Rev. Endocrinol. 2019, 15, 288-298. [CrossRef]

5. Yanovski, J.A. Obesity: Trends in underweight and obesity-scale of the problem. Nat. Rev. Endocrinol. 2018, 14, 5-6. [CrossRef] 
6. Canfora, E.E.; Jocken, J.W.; Blaak, E.E. Short-chain fatty acids in control of body weight and insulin sensitivity. Nat. Rev. Endocrinol. 2015, 11, 577-591. [CrossRef] [PubMed]

7. Bäckhed, F.; Ding, H.; Wang, T.; Hooper, L.V.; Koh, G.Y.; Nagy, A.; Semenkovich, C.F.; Gordon, J.I. The gut microbiota as an environmental factor that regulates fat storage. Proc. Natl Acad Sci. USA 2004, 101, 15718-15723. [CrossRef] [PubMed]

8. Goodrich, J.K.; Waters, J.L.; Poole, A.C.; Sutter, J.L.; Koren, O.; Blekhman, R.; Beaumont, M.; Van Treuren, W.; Knight, R.; Bell, J.T.; et al. Human genetics shape the gut microbiome. Cell 2014, 159, 789-799. [CrossRef] [PubMed]

9. Isolauri, E. Microbiota and Obesity. Nestle Nutr Inst. Workshop Ser. 2017, 88, 95-105.

10. Cani, P.D. Human gut microbiome: Hopes, threats and promises. Gut 2018, 67, 1716-1725. [CrossRef]

11. Fava, F.; Rizzetto, L.; Tuohy, K.M. Gut microbiota and health: Connecting actors across the metabolic system. Proc. Nutr Soc. 2018, 78, 1-12. [CrossRef]

12. Knudsen, K.E.B.; Lærke, H.N.; Hedemann, M.S.; Nielsen, T.S.; Ingerslev, A.K.; Nielsen, D.S.G.; Theil, P.K.; Purup, S.; Hald, S.; Schioldan, A.G.; et al. Impact of diet-modulated butyrate production on intestinal barrier function and inflammation. Nutrients 2018, 10, 1499. [CrossRef] [PubMed]

13. Gentile, C.L.; Weir, T.L. The gut microbiota at the intersection of diet and human health. Science 2018, 362, 776-780. [CrossRef] [PubMed]

14. Sonnenburg, J.L.; Bäckhed, F. Diet-microbiota interactions as moderators of human metabolism. Nature 2016, 535, 56-64. [CrossRef] [PubMed]

15. Sonnenburg, E.D.; Smits, S.A.; Tikhonov, M.; Higginbottom, S.K.; Wingreen, N.S.; Sonnenburg, J.L. Diet-induced extinctions in the gut microbiota compound over generations. Nature 2016, 529, 212-215. [CrossRef] [PubMed]

16. Turnbaugh, P.J.; Bäckhed, F.; Fulton, L.; Gordon, J.I. Diet-induced obesity is linked to marked but reversible alterations in the mouse distal gut microbiome. Cell Host Microbe 2008, 3, 213-223. [CrossRef] [PubMed]

17. Louis, P.; Flint, H.J. Formation of propionate and butyrate by the human colonic microbiota. Environ. Microbiol. 2017, 19, 29-41. [CrossRef]

18. Brahe, L.K.; Astrup, A.; Larsen, L.H. Is butyrate the link between diet, intestinal microbiota and obesity-related metabolic diseases? Obes Rev. 2013, 14, 950-959. [CrossRef]

19. Banasiewicz, T.; Domagalska, D.; Borycka-Kiciak, K.; Rydzewska, G. Determination of butyric acid dosage based on clinical and experimental studies-a literature review. Prz Gastroenterol. 2020, 15, 119-125. [CrossRef]

20. LeBlanc, J.G.; Chain, F.; Martín, R.; Bermúdez-Humarán, L.G.; Courau, S.; Langella, P. Beneficial effects on host energy metabolism of short-chain fatty acids and vitamins produced by commensal and probiotic bacteria. Microb Cell Fact. 2017, 16, 79. [CrossRef]

21. Human Microbiome Project Consortium. Structure, function and diversity of the healthy human microbiome. Nature 2012, 486, 207-214. [CrossRef]

22. Thorburn, A.N.; Macia, L.; Mackay, C.R. Diet, metabolites, and "western-lifestyle" inflammatory diseases. Immunity 2014, 40, 833-842. [CrossRef] [PubMed]

23. Sommer, F.; Bäckhed, F. The gut microbiota-Masters of host development and physiology. Nat. Rev. Microbiol. 2013, 11, 227-238. [CrossRef] [PubMed]

24. Whelan, K.; Schneider, S.M. Mechanisms, prevention, and management of diarrhea in enteral nutrition. Curr. Opin. Gastroenterol. 2011, 27, 152-159. [CrossRef] [PubMed]

25. Zeller, I.; Malovichko, M.V.; Hurst, H.E.; Renaud, D.E.; Scott, D.A. Cigarette smoke reduces short chain fatty acid production by a Porphyromonas gingivalis clinical isolate. J. Periodontal Res. 2019, 54, 566-571. [CrossRef] [PubMed]

26. Couch, R.D.; Dailey, A.; Zaidi, F.; Navarro, K.; Forsyth, C.B.; Mutlu, E.; Engen, P.A.; Keshavarzian, A. Alcohol induced alterations to the human fecal VOC metabolome. PLoS ONE 2015, 10, e0119362. [CrossRef]

27. Cummings, J.H.; Stephen, A.M. Carbohydrate terminology and classification. Eur, J. Clin. Nutr. 2007, 61, 5-18. [CrossRef] [PubMed]

28. Collins, K.H.; Herzog, W.; MacDonald, G.Z.; Reimer, R.A.; Rios, J.L.; Smith, I.C.; Zernicke, R.F.; Hart, D.A. Obesity, metabolic syndrome, and musculoskeletal disease: Common inflammatory pathways suggest a central role for loss of muscle integrity. Front. Physiol. 2018, 9, 112. [CrossRef]

29. Mastrocola, R.; Ferrocino, I.; Liberto, E.; Chiazza, F.; Cento, A.S.; Collotta, D.; Querio, G.; Nigro, D.; Bitonto, V.; Cutrin, J.C.; et al. Fructose liquid and solid formulations differently affect gut integrity, microbiota composition and related liver toxicity: A comparative in vivo study. J. Nutr Biochem. 2018, 55, 185-199. [CrossRef]

30. Zmora, N.; Suez, J.; Elinav, E. You are what you eat: Diet, health and the gut microbiota. Nat. Rev. Gastroenterol. Hepatol. 2019, 16, 35-56. [CrossRef]

31. So, D.; Whelan, K.; Rossi, M.; Morrison, M.; Holtmann, G.; Kelly, J.T.; Shanahan, E.R.; Staudacher, H.M.; Campbell, K.L. Dietary fiber intervention on gut microbiota composition in healthy adults: A systematic review and meta-analysis. Am. J. Clin. Nutr. 2018, 107, 965-983. [CrossRef]

32. Russell, W.R.; Gratz, S.W.; Duncan, S.H.; Holtrop, G.; Ince, J.; Scobbie, L.; Duncan, G.; Johnstone, A.M.; Lobley, G.E.; Wallace, R.J.; et al. High-protein, reduced-carbohydrate weight-loss diets promote metabolite profiles likely to be detrimental to colonic health. Am. J. Clin. Nutr. 2011, 93, 1062-1072. [CrossRef] [PubMed] 
33. De Filippis, F.; Pellegrini, N.; Vannini, L.; Jeffery, I.B.; La Storia, A.; Laghi, L.; Serrazanetti, D.I.; Di Cagno, R.; Ferrocino, I.; Lazzi, C.; et al. High-level adherence to a Mediterranean diet beneficially impacts the gut microbiota and associated metabolome. Gut 2016, 65, 1812-1821. [CrossRef] [PubMed]

34. Singh, R.K.; Chang, H.W.; Yan, D.; Lee, K.M.; Ucmak, D.; Wong, K.; Abrouk, M.; Farahnik, B.; Nakamura, M.; Zhu, T.H.; et al. Influence of diet on the gut microbiome and implications for human health. J. Transl. Med. 2017, 15, 73. [CrossRef] [PubMed]

35. Carmody, R.N.; Gerber, G.K.; Luevano, J.M., Jr.; Gatti, D.M.; Somes, L.; Svenson, K.L.; Turnbaugh, P.J. Diet dominates host genotype in shaping the murine gut microbiota. Cell Host Microbe 2015, 17, 72-84. [CrossRef] [PubMed]

36. Kaczmarek, J.L.; Musaad, S.M.; Holscher, H.D. Time of day and eating behaviors are associated with the composition and function of the human gastrointestinal microbiota. Am. J. Clin. Nutr. 2017, 75, 673-682. [CrossRef]

37. Caporaso, J.G.; Lauber, C.L.; Costello, E.K.; Berg-Lyons, D.; Gonzalez, A.; Stombaugh, J.; Knights, D.; Gajer, P.; Ravel, J.; Fierer, N.; et al. Moving pictures of the human microbiome. Genome Biol. 2011, 12, R50. [CrossRef]

38. Leone, V.; Gibbons, S.M.; Martinez, K.; Hutchison, A.L.; Huang, E.Y.; Cham, C.M.; Pierre, J.F.; Heneghan, A.F.; Nadimpalli, A.; Hubert, N.; et al. Effects of diurnal variation of gut microbes and high-fat feeding on host circadian clock function and metabolism. Cell Host Microbe 2015, 17, 681-689. [CrossRef]

39. Marchesi, J.R.; Adams, D.H.; Fava, F.; Hermes, G.D.; Hirschfield, G.M.; Hold, G.; Quraishi, M.N.; Kinross, J.; Smidt, H.; Tuohy, K.M.; et al. The gut microbiota and host health: A new clinical frontier. Gut 2016, 65, 330-339. [CrossRef] [PubMed]

40. Fernandes, J.; Su, W.; Rahat-Rozenbloom, S.; Wolever, T.M.; Comelli, E.M. Adiposity, gut microbiota and faecal short chain fatty acids are linked in adult humans. Nutr. Diabetes 2014, 4, e121. [CrossRef]

41. Rios-Covian, D.; Ruas-Madiedo, P.; Margolles, A.; Gueimonde, M.; de Los Reyes-Gavilan, C.G.; Salazar, N. Intestinal Short Chain Fatty Acids and their link with diet and human health. Front. Microbiol. 2016, 7, 185. [CrossRef]

42. David, L.A.; Maurice, C.F.; Carmody, R.N.; Gootenberg, D.B.; Button, J.E.; Wolfe, B.E.; Ling, A.V.; Devlin, A.S.; Varma, Y.; Fischbach, M.A.; et al. Diet rapidly and reproducibly alters the human gut microbiome. Nature 2014, 505, 559-563. [CrossRef] [PubMed]

43. O'Keefe, S.J.; Li, J.V.; Lahti, L.; Ou, J.; Carbonero, F.; Mohammed, K.; Posma, J.M.; Kinross, J.; Wahl, E.; Ruder, E.; et al. Fat, fibre and cancer risk in African Americans and rural Africans. Nat. Commun. 2015, 6, 6342.

44. Duncan, S.H.; Hold, G.L.; Barcenilla, A.; Stewart, C.S.; Flint, H.J. Roseburia intestinalis sp. nov., a novel saccharolytic, butyrateproducing bacterium from human faeces. Int. J. Syst. Evol. Microbiol. 2002, 52, 1615-1620. [PubMed]

45. Khan, S.; Jena, G. The role of butyrate, a histone deacetylase inhibitor in diabetes mellitus: Experimental evidence for therapeutic intervention. Epigenomics 2015, 7, 669-680. [CrossRef] [PubMed]

46. Vital, M.; Karch, A.; Pieper, D.H. Colonic butyrate-producing communities in humans: An overview using omics data. $m S y s t e m s$ 2017, 2, e00130-17. [CrossRef]

47. Sajilata, M.G.; Singhal, R.S.; Kulkarni, P.R. Resistant Starch-A Review. Compr. Rev. Food Sci. Food Saf. 2017, 5, 1-17. [CrossRef] [PubMed]

48. Raigond, P.; Ezekiel, R.; Raigond, B. Resistant starch in food: A review. J. Sci. Food Agric. 2015, 95, 1968-1978. [CrossRef]

49. Dai, Z.L.; Wu, G.; Zhu, W.Y. Amino acid metabolism in intestinal bacteria: Links between gut ecology and host health. Front. Biosci. (Landmark Ed.) 2011, 16, 1768-1786. [CrossRef]

50. USDA National Nutrient Database for Standard Reference. Available online: https://fdc.nal.usda.gov/ndb/ (accessed on 10 December 2020).

51. Wang, M.; Li, M.; Wu, S.; Lebrilla, C.B.; Chapkin, R.S.; Ivanov, I.; Donovan, S.M. Fecal microbiota composition of breast-fed infants is correlated with human milk oligosaccharides consumed. J. Pediatr. Gastroenterol. Nutr. 2015, 60, 825-833. [CrossRef]

52. Jost, T.; Lacroix, C.; Braegger, C.P.; Rochat, F.; Chassard, C. Vertical mother-neonate transfer of maternal gut bacteria via breastfeeding. Environ. Microbiol. 2014, 16, 2891-2904. [CrossRef]

53. Walker, W.A.; Iyengar, R.S. Breast milk, microbiota and intestinal immune homeostasis. Pediatr. Res. 2015, 77, 220-228. [CrossRef] [PubMed]

54. Padilha, M.; Danneskiold-Samsøe, N.B.; Brejnrod, A.; Hoffmann, C.; Cabral, V.P.; Iaucci, J.M.; Sales, C.H.; Fisberg, R.M.; Cortez, R.V.; Brix, S.; et al. The human milk microbiota is modulated by maternal diet. Microorganisms 2019, 7, 502. [CrossRef] [PubMed]

55. Moossavi, S.; Sepehri, S.; Robertson, B.; Bode, L.; Goruk, S.; Field, C.J.; Lix, L.M.; de Souza, R.J.; Becker, A.B.; Mandhane, P.J.; et al. Composition and variation of the human milk microbiota are influenced by maternal and early-life factors. Cell Host Microbe 2019, 25, 324-335. [CrossRef] [PubMed]

56. Moossavi, S.; Atakora, F.; Miliku, K.; Sepehri, S.; Robertson, B.; Duan, Q.L.; Becker, A.B.; Mandhane, P.J.; Turvey, S.E.; Moraes, T.J.; et al. Integrated analysis of human milk microbiota with oligosaccharides and fatty acids in the CHILD cohort. Front. Nutr. 2019, 6, 58. [CrossRef] [PubMed]

57. McGuire, M.K.; McGuire, M.A. Got bacteria? The astounding, yet not-so-surprising, microbiome of human milk. Curr. Opin. Biotechnol. 2017, 44, 63-68. [CrossRef]

58. Rautava, S. Early microbial contact, the breast milk microbiome and child health. J. Dev. Orig. Health Dis. 2016, 7, 5-14. [CrossRef] [PubMed]

59. Munblit, D.; Verhasselt, V. Allergy prevention by breastfeeding: Possible mechanisms and evidence from human cohorts. Curr. Opin. Allergy Clin. Immunol. 2016, 16, 427-433. [CrossRef] 
60. Louis, P.; Flint, H.J. Diversity, metabolism and microbial ecology of butyrate-producing bacteria from the human large intestine. FEMS Microbiol. Lett. 2009, 294, 1-8. [CrossRef] [PubMed]

61. Moens, F.; Weckx, S.; De Vuyst, L. Bifidobacterial inulin-type fructan degradation capacity determines cross-feeding interactions between bifidobacteria and Faecalibacterium prausnitzii. Int. J. Food Microbiol. 2016, 231, 76-85. [CrossRef]

62. Hua, X.; Zhu, J.; Yang, T.; Guo, M.; Li, Q.; Chen, J.; Li, T. The gut microbiota and associated metabolites are altered in sleep disorder of children with autism spectrum disorders. Front. Psychiatry 2020, 11, 855. [CrossRef]

63. Seo, M.; Anderson, G. Gut-Amygdala interactions in Autism Spectrum Disorders: Developmental roles via regulating mitochondria, exosomes, immunity and microRNAs. Curr. Pharm. Des. 2019, 25, 4344-4356. [CrossRef] [PubMed]

64. Blaak, E.E.; Canfora, E.E.; Theis, S.; Frost, G.; Groen, A.K.; Mithieux, G.; Nauta, A.; Scott, K.; Stahl, B.; van Harsselaar, J.; et al. Short chain fatty acids in human gut and metabolic health. Benef. Microbes 2020, 11, 411-455. [CrossRef] [PubMed]

65. Bouter, K.E.C.; Bakker, G.J.; Levin, E.; Hartstra, A.V.; Kootte, R.S.; Udayappan, S.D.; Katiraei, S.; Bahler, L.; Gilijamse, P.W.; Tremaroli, V. Differential metabolic effects of oral butyrate treatment in lean versus metabolic syndrome subjects. Clin. Transl. Gastroenterol. 2018, 9, 155. [CrossRef] [PubMed]

66. Kootte, R.S.; Levin, E.; Salojärvi, J.; Smits, L.P.; Hartstra, A.V.; Udayappan, S.D.; Hermes, G.; Bouter, K.E.; Koopen, A.M.; Holst, J.J.; et al. Improvement of insulin sensitivity after lean donor feces in metabolic syndrome is driven by baseline intestinal microbiota composition. Cell Metab. 2017, 26, 611-619. [CrossRef] [PubMed]

67. Neis, E.P.J.G.; Van Eijk, H.M.H.; Lenaerts, K.; OldeDamink, S.W.M.; Blaak, E.E.; Dejong, C.H.C.; Rensen, S.S. Distal versus proximal intestinal short-chain fatty acid release in man. Gut 2018, 68, 764-765. [CrossRef] [PubMed]

68. Van der Beek, C.M.; Bloemen, J.G.; Van den Broek, M.A.; Lenaerts, K.; Venema, K.; Buurman, W.A.; Dejong, C.H. Hepatic uptake of rectally administered butyrate prevents an increase in systemic butyrate concentrations in humans. J. Nutr. 2015, 145, 2019-2024. [CrossRef] [PubMed]

69. Kasubuchi, M.; Hasegawa, S.; Hiramatsu, T.; Ichimura, A.; Kimura, I. Dietary gut microbial metabolites, short-chain fatty acids, and host metabolic regulation. Nutrients 2015, 7, 2839-2849. [CrossRef]

70. Bloemen, J.G.; Venema, K.; van de Poll, M.C.; Olde Damink, S.W.; Buurman, W.A.; Dejong, C.H. Short chain fatty acids exchange across the gut and liver in humans measured at surgery. Clin. Nutr. 2009, 28, 657-661. [CrossRef]

71. Boets, E.; Gomand, S.V.; Deroover, L.; Preston, T.; Vermeulen, K.; De Preter, V.; Hamer, H.M.; Van den Mooter, G.; De Vuyst, L.; Courtin, C.M.; et al. Systemic availability and metabolism of colonic-derived short-chain fatty acids in healthy subjects: A stable isotope study. J. Physiol. 2017, 595, 541-555. [CrossRef]

72. Ganapathy, V.; Thangaraju, M.; Prasad, P.D.; Martin, P.M.; Singh, N. Transporters and receptors for short-chain fatty acids as the molecular link between colonic bacteria and the host. Curr. Opin. Pharmacol. 2013, 13, 869-874. [CrossRef]

73. Charney, A.N.; Micic, L.; Egnor, R.W. Nonionic diffusion of short-chain fatty acids across rat colon. Am. J. Physiol. 1998, 274, 518-524. [CrossRef] [PubMed]

74. Wong, J.M.; de Souza, R.; Kendall, C.W.; Emam, A.; Jenkins, D.J. Colonic health: Fermentation and short chain fatty acids. J. Clin. Gastroenterol. 2006, 40, 235-243. [CrossRef] [PubMed]

75. Bergman, E.N. Energy contributions of volatile fatty acids from the gastrointestinal tract in various species. Physiol. Rev. 1990, 70, 567-590. [CrossRef] [PubMed]

76. Cresci, G.A.; Thangaraju, M.; Mellinger, J.D.; Liu, K.; Ganapathy, V. Colonic gene expression in conventional and germ-free mice with a focus on the butyrate receptor GPR 109A and the butyrate transporter SLC5A8. J. Gastrointest. Surg. 2010, 14, 449-461. [CrossRef] [PubMed]

77. Gupta, N.; Martin, P.M.; Prasad, P.D.; Ganapathyet, V. SLC5A8 (SMCT1)-mediated transport of butyrate forms the basis for the tumor suppressive function of the transporter. Life Sci. 2006, 78, 2419-2425. [CrossRef] [PubMed]

78. Takebe, K.; Nio, J.; Morimatsu, M.; Karaki, S.; Kuwahara, A.; Kato, I.; Iwanaga, T. Histochemical demonstration of a Na(+)-coupled transporter for short-chain fatty acids (slc5a8) in the intestine and kidney of the mouse. Biomed. Res. 2005, 26, 213-221. [CrossRef] [PubMed]

79. Hu, J.; Lin, S.; Zheng, B.; Cheung, P.C. Short-chain fatty acids in control of energy metabolism. Crit. Rev. Food Sci. Nutr. 2016, 58, 1243-1249. [CrossRef]

80. Harig, J.M.; Ng, E.K.; Dudeja, P.K.; Brasitus, T.A.; Ramaswamy, K. Transport of n-butyrate into human colonic luminal membrane vesicles. Am. J. Physiol. 1996, 271, 415-422. [CrossRef]

81. Ritzhaupt, A.; Ellis, A.; Hosie, K.B.; Shirazi-Beechey, S.P. The characterization of butyrate transport across pig and human colonic luminal membrane. J. Physiol. 1998, 507, 819-830. [CrossRef]

82. Stilling, R.M.; van de Wouw, M.; Clarke, G.; Stanton, C.; Dinan, T.G.; Cryan, J.F. The neuropharmacology of butyrate: The bread and butter of the microbiota-gut-brain axis? Neurochem. Int. 2016, 99, 110-132. [CrossRef]

83. Ahmad, M.S.; Krishnan, S.; Ramakrishna, B.S.; Mathan, M.; Pulimood, A.B.; Murthy, S.N. Butyrate and glucose metabolism by colonocytes in experimental colitis in mice. Gut 2000, 46, 493-499. [CrossRef] [PubMed]

84. Brown, A.J.; Goldsworthy, S.M.; Barnes, A.A.; Eilert, M.M.; Tcheang, L.; Daniels, D.; Muir, A.I.; Wigglesworth, M.J.; Kinghorn, I.; Fraser, N.J.; et al. The orphan G protein-coupled receptors GPR 41 and GPR 43 are activated by propionate and other short chain carboxylic acids. J. Biol. Chem. 2003, 278, 11312-11319. [CrossRef] [PubMed]

85. Bindels, L.B.; Dewulf, E.M.; Delzenne, N.M. GPR43/FFA2, physiopathological relevance and therapeutic prospects. Trends Pharmacol. Sci. 2013, 34, 226-232. [CrossRef] [PubMed] 
86. Macia, L.; Tan, J.; Vieira, A.T.; Leach, K.; Stanley, D.; Luong, S.; Maruya, M.; Ian McKenzie, C.; Hijikata, A.; Wong, C.; et al. Metabolite sensing receptors GPR43 and GPR109A facilitate dietary fibre-induced gut homeostasis through regulation of the inflammasome. Nat. Commun. 2015, 6, 1-15. [CrossRef] [PubMed]

87. Kim, C.H.; Park, J.; Kim, M. Gut Microbiota-Derived Short-Chain Fatty Acids, T Cells, and Inflammation. Immune Netw. 2014, 14, 277-288. [CrossRef]

88. Sleeth, M.L.; Thompson, E.L.; Ford, H.E.; Zac-Varghese, S.E. Frost G Free fatty acid receptor 2 and nutrient sensing: A proposed role for fibre, fermentable carbohydrates and short-chain fatty acids in appetite regulation. Nutr. Res. Rev. 2010, 23, 135-145. [CrossRef]

89. Kimura, I.; Miyamoto, J.; Ohue-Kitano, R.; Watanabe, K.; Yamada, T.; Onuki, M.; Aoki, R.; Isobe, Y.; Kashihara, D.; Inoue, D.; et al. Maternal gut microbiota in pregnancy influences offspring metabolic phenotype in mice. Science 2020, 367, eaaw8429. [CrossRef]

90. Le Poul, E.; Loison, C.; Struyf, S.; Springael, J.Y.; Lannoy, V.; Decobecq, M.-E.; Brezillon, S.; Dupriez, V.; Vassart, G.; Van Damme, J.; et al. Functional characterization of human receptors for short chain fatty acids and their role in polymorphonuclear cell activation. J. Biol Chem. 2003, 278, 25481-25489. [CrossRef]

91. Goldsmith, Z.G.; Dhanasekaran, D.N. G protein regulation of MAPK networks. Oncogene 2007, 26, 3122-3142. [CrossRef]

92. Kim, M.H.; Kang, S.G.; Park, J.H.; Yanagisawa, M.; Kim, C.H. Short-Chain Fatty Acids Activate GPR 41 and GPR 43 on Intestinal Epithelial Cells to Promote Inflammatory Responses in Mice. Gastroenterology 2013, 145, 396-406. [CrossRef]

93. D'Souza, W.N.; Douangpanya, J.; Mu, S.; Jaeckel, P.; Zhang, M.; Maxwell, J.R.; Rottman, J.B.; Labitzke, K.; Willee, A.; Beckmann, H.; et al. Differing roles for short chain fatty acids and GPR 43 agonism in the regulation of intestinal barrier function and immune responses. PLoS ONE 2017, 12, e0180190. [CrossRef] [PubMed]

94. Tolhurst, G.; Heffron, H.; Lam, Y.S.; Parker, H.E.; Habib, A.M.; Diakogiannaki, E.; Cameron, J.; Grosse, J.; Reimann, F.; Gribble, F.M. Short-chain fatty acids stimulate glucagon-like peptide-1 secretion via the G-protein-coupled receptor FFAR2. Diabetes 2012, 61, 364-371. [CrossRef] [PubMed]

95. Plaisancié, P.; Dumoulin, V.; Chayvialle, J.A.; Cuber, J.C. Luminal peptide YY-releasing factors in the isolated vascularly perfused rat colon. J. Endocrinol. 1996, 151, 421-429. [CrossRef] [PubMed]

96. Samuel, B.S.; Shaito, A.; Motoike, T.; Rey, F.E.; Backhed, F.; Manchester, J.K.; Hammer, R.E.; Williams, S.C.; Crowley, J.; Yanagisawa, M.; et al. Effects of the gut microbiota on host adiposity are modulated by the short-chain fatty-acid binding $\mathrm{G}$ protein-coupled receptor, Gpr41. Proc. Natl. Acad. Sci. USA 2008, 105, 16767-16772. [CrossRef] [PubMed]

97. Chelikani, P.K.; Haver, A.C.; Reidelberger, R.D. Intravenous Infusion of Peptide YY (3-36) Potently Inhibits Food Intake in Rats. Endocrinology 2005, 146, 879-888. [CrossRef]

98. Flint, A.; Raben, A.; Astrup, A.; Holst, J.J. Glucagon-like peptide 1 promotes satiety and suppresses energy intake in humans. J. Clin. Investig. 1998, 101, 515-520. [CrossRef] [PubMed]

99. Meyer-Ficca, M.; Kirkland, J.B. Niacin. Adv. Nutr. Int. Rev. 2016, 7, 556-558. [CrossRef]

100. Wong, T.; Chan, L.; Leung, P. Involvement of the niacin receptor GPR 109a in the local control of glucose uptake in small intestine of type 2 diabetic mice. Nutrients 2015, 7, 5352. [CrossRef]

101. Steliou, K.; Boosalis, M.S.; Perrine, S.P.; Sangerman, J.; Faller, D.V. Butyrate histone deacetylase inhibitors. Bio Res. Open Access 2012, 1, 192-198. [CrossRef]

102. Davie, J.R. Inhibition of Histone Deacetylase Activity by Butyrate. J. Nutr. 2003, 133, 2485S-2493S. [CrossRef]

103. Kratsman, N.; Getselter, D.; Elliott, E. Sodium butyrate attenuates social behavior deficits and modifies the transcription of inhibitory/excitatory genes in the frontal cortex of an autism model. Neuropharmacology 2016, 102, 136-145. [CrossRef] [PubMed]

104. Rose, S.; Bennuri, S.C.; Davis, J.E.; Wynne, R.; Slattery, J.C.; Tippett, M.; Delhey, L.; Melnyk, S.; Kahler, S.G.; MacFabe, D.F.; et al. Butyrate enhances mitochondrial function during oxidative stress in cell lines from boys with autism. Transl. Psychiatry 2018, 8, 42. [CrossRef] [PubMed]

105. Berding, K.; Donovan, S.M. Dietary patterns impact temporal dynamics of fecal microbiota composition in children with Autism Spectrum Disorder. Front. Nutr. 2020, 6, 193. [CrossRef] [PubMed]

106. Plöger, S.; Stumpff, F.; Penner, G.B.; Schulzke, J.D.; Gäbel, G.; Martens, H.; Shen, Z.; Günzel, D.; Aschenbach, J.R. Microbial butyrate and its role for barrier function in the gastrointestinal tract. Ann. N. Y. Acad. Sci. 2012, 1258, 52-59.

107. Wang, H.B.; Wang, P.Y.; Wang, X.; Wan, Y.L.; Liu, Y.C. Butyrate enhances intestinal epithelial barrier function via up-regulation of tight junction protein Claudin-1 transcription. Dig. Dis Sci. 2012, 57, 3126-3135. [CrossRef] [PubMed]

108. Peng, L.; Li, Z.R.; Green, R.S.; Holzman, I.R.; Lin, J. Butyrate enhances the intestinal barrier by facilitating tight junction assembly via activation of AMP-activated protein kinase in Caco-2 cell monolayers. J. Nutr. 2009, 139, 1619-1625. [CrossRef] [PubMed]

109. Lewis, K.; Lutgendorff, F.; Phan, V.; Söderholm, J.D.; Sherman, P.M.; McKay, D.M. Enhanced translocation of bacteria across metabolically stressed epithelia is reduced by butyrate. Inflamm. Bowel Dis. 2010, 16, 1138-1148. [CrossRef] [PubMed]

110. Kinoshita, M.; Suzuki, Y.; Saito, Y. Butyrate reduces colonic paracellular permeability by enhancing PPAR gamma activation. Biochem. Biophys. Res. Commun. 2002, 293, 827-831. [CrossRef]

111. Fukushima, A.; Aizaki, Y.; Sakuma, K. Short-chain fatty acids induce intestinal transient receptor potential vanilloid type 6 expression in rats and Caco-2 cells. J. Nutr. 2009, 139, 20-25. [CrossRef]

112. Ziegler, K.; Kerimi, A.; Poquet, L.; Williamson, G. Butyric acid increases transepithelial transport of ferulic acid through upregulation of the monocarboxylate transporters SLC16A1 (MCT1) and SLC16A3 (MCT4). Arch. Biochem. Biophys. 2016, 599, 3-12. [CrossRef] 
113. Kliewer, S.A.; Lenhard, J.M.; Willson, T.M.; Patel, I.; Morris, D.C.; Lehmann, J.M. A prostaglandin J2 metabolite binds peroxisome proliferator-activated receptor gamma and promotes adipocyte differentiation. Cell 1995, 83, 813-819. [CrossRef]

114. Hamer, H.M.; Jonkers, D.; Venema, K.; Vanhoutvin, S.; Troost, F.J.; Brummer, R.J. Review article: The role of butyrate on colonic function. Aliment. Pharmacol. Ther. 2008, 27, 104-119. [CrossRef] [PubMed]

115. Byndloss, M.X.; Olsan, E.E.; Rivera-Chávez, F.; Tiffany, C.R.; Cevallos, S.A.; Lokken, K.L.; Torres, T.P.; Byndloss, A.J.; Faber, F.; Gao, Y.; et al. Microbiota-activated PPAR- $\gamma$ signaling inhibits dysbiotic Enterobacteriaceae expansion. Science 2017, 357, 570-575. [CrossRef] [PubMed]

116. Segain, J.P.; Raingeard de la Bletiere, D.; Boureille, A.; Leray, V.; Gervois, N.; Rosales, C.; Ferrier, L.; Bonnet, C.; Blottiere, H.M.; Glamiche, J.P. Butyrate inhibits inflammatory responses through NF kappa B inhibition: Implications for Crohn's disease. Gut 2000, 47, 397-403. [CrossRef] [PubMed]

117. Luhrs, H.; Gerke, T.; Schauber, J.; Dusel, G.; Scheppach, W.; Menzel, T. Cytokine-activated degradation of inhibitory kappa B protein alpha is inhibited by the short chain fatty acid butyrate. Int. J. Colorect. Dis. 2001, 16, 195-201.

118. Csordas, A. Butyrate, aspirin and colorectal cancer. Eur. J. Cancer Prevent. 1996, 5, 221-231. [CrossRef] [PubMed]

119. Fang, W.; Xue, H.; Chen, X.; Chen, K.; Ling, W. Supplementation with sodium butyrate modulates the composition of the gut microbiota and ameliorates high-fat diet-induced obesity in mice. J. Nutr. 2019, 149, 747-754. [CrossRef] [PubMed]

120. Arnoldussen, I.A.C.; Wiesmann, M.; Pelgrim, C.E.; Wielemaker, E.M.; van Duyvenvoorde, W.; Amaral-Santos, P.L.; Verschuren, L.; Keijser, B.J.F.; Heerschap, A.; Kleemann, R.; et al. Butyrate restores HFD-induced adaptations in brain function and metabolism in mid-adult obese mice. Int. J. Obes. (Lond.) 2017, 41, 935-944. [CrossRef]

121. Pelgrim, C.E.; Franx, B.A.A.; Snabel, J.; Kleemann, R.; Arnoldussen, I.A.C.; Kiliaan, A.J. Butyrate reduces HFD-induced adipocyte hypertrophy and metabolic risk factors in obese LDLr-/- Leiden mice. Nutrients 2017, 9, 714. [CrossRef]

122. Henagan, T.M.; Stefanska, B.; Fang, Z.; Navard, A.M.; Ye, J.; Lenard, N.R.; Devarshi, P.P. Sodium butyrate epigenetically modulates high-fat diet-induced skeletal muscle mitochondrial adaptation, obesity and insulin resistance through nucleosome positioning. Br. J. Pharmacol. 2015, 172, 2782-2798. [CrossRef]

123. MattaceRaso, G.; Simeoli, R.; Russo, R.; Iacono, A.; Santoro, A.; Paciello, O.; Ferrante, M.C.; Canani, R.B.; Calignano, A.; Meli, R. Effects of sodium butyrate and its synthetic amide derivative on liver inflammation and glucose tolerance in an animal model of steatosis induced by high fat diet. PLoS ONE 2013, 8, e68626.

124. Matheus, V.A.; Monteiro, L.; Oliveira, R.B.; Maschio, D.A.; Collares-Buzato, C.B. Butyrate reduces high-fat diet-induced metabolic alterations, hepatic steatosis and pancreatic beta cell and intestinal barrier dysfunctions in prediabetic mice. Exp. Biol. Med. (Maywood) 2017, 242, 1214-1226. [CrossRef] [PubMed]

125. Hong, J.; Jia, Y.; Pan, S.; Jia, L.; Li, H.; Han, Z.; Cai, D.; Zhao, R. Butyrate alleviates high fat diet-induced obesity through activation of adiponectin-mediated pathway and stimulation of mitochondrial function in the skeletal muscle of mice. Oncotarget 2016, 7, 56071-56082. [CrossRef] [PubMed]

126. den Besten, G.; Bleeker, A.; Gerding, A.; van Eunen, K.; Havinga, R.; van Dijk, T.H.; Oosterveer, M.H.; Jonker, J.W.; Groen, A.K.; Reijngoud, D.J.; et al. Short-chain fatty acids protect against high-fat diet-induced obesity via a PPAR $\gamma$-dependent switch from lipogenesis to fat oxidation. Diabetes 2015, 64, 2398-2408. [CrossRef] [PubMed]

127. Gao, Z.; Yin, J.; Zhang, J.; Ward, R.E.; Martin, R.J.; Lefevre, M.; Cefalu, W.T.; Ye, J. Butyrate improves insulin sensitivity and increases energy expenditure in mice. Diabetes 2009, 58, 1509-1517. [CrossRef] [PubMed]

128. Wang, D.; Liu, C.; Li, H.; Tian, M.; Pan, J.; Shu, G.; Jiang, Q.; Yin, Y.; Zhang, L. LSD1 mediates microbial metabolite butyrateinduced thermogenesis in brown and white adipose tissue. Metabolism 2020, 102, 154011. [CrossRef]

129. Jia, Y.; Hong, J.; Li, H.; Hu, Y.; Jia, L.; Cai, D.; Zhao, R. Butyrate stimulates adipose lipolysis and mitochondrial oxidative phosphorylation through histone hyperacetylation-associated $\beta 3$-adrenergic receptor activation in high-fat diet-induced obese mice. Exp. Physiol. 2017, 102, 273-281. [CrossRef]

130. Li, Z.; Yi, C.X.; Katiraei, S.; Kooijman, S.; Zhou, E.; Chung, C.K.; Gao, Y.; van den Heuvel, J.K.; Meijer, O.C.; Berbée, J.F.P.; et al. Butyrate reduces appetite and activates brown adipose tissue via the gut-brain neural circuit. Gut 2018, 67, 1269-1279. [CrossRef]

131. Lin, H.V.; Frassetto, A.; Kowalik, E.J., Jr.; Nawrocki, A.R.; Lu, M.M.; Kosinski, J.R.; Hubert, J.A.; Szeto, D.; Yao, X.; Forrest, G.; et al. Butyrate and propionate protect against diet-induced obesity and regulate gut hormones via free fatty acid receptor 3-independent mechanisms. PLoS ONE 2012, 7, e35240. [CrossRef]

132. Canfora, E.E.; van der Beek, C.M.; Jocken, J.W.E.; Goossens, G.H.; Holst, J.J.; Damink, S.W.M.O.; Lenaerts, J.; Dejong, C.H.C.; Blaak, E.E. Colonic infusions of short-chain fatty acid mixtures promote energy metabolism in overweight/obese men: A randomized crossover trial. Sci Rep. 2017, 7, 2360. [CrossRef]

133. Cleophas, M.C.P.; Ratter, J.M.; Bekkering, S.; Quintin, J.; Schraa, K.; Stroes, E.S.; Netea, M.G.; Joosten, L.A.B. Effects of oral butyrate supplementation on inflammatory potential of circulating peripheral blood mononuclear cells in healthy and obese males. Sci Rep. 2019, 9, 775. [CrossRef] [PubMed]

134. Ivanov, D.O.; Evsyukova, I.I.; Mazzoccoli, G.; Anderson, G.; Polyakova, V.O.; Kvetnoy, I.M.; Carbone, A.; Nasyrov, R.A. The role of prenatal melatonin in the regulation of childhood obesity. Biology (Basel) 2020, 9, 72. [CrossRef] [PubMed]

135. Sinha, R.A.; Bruinstroop, E.; Singh, B.K.; Yen, P.M. Non-alcoholic fatty liver disease and hypercholesterolemia: Roles of thyroid hormones, metabolites, and agonists. Thyroid 2019, 29, 1173-1191. [CrossRef] [PubMed]

136. Hara, H.; Haga, S.; Aoyama, Y.; Kiriyama, S. Short-chain fatty acids suppress cholesterol synthesis in rat liver and intestine. J. Nutr. 1999, 129, 942-948. [CrossRef] [PubMed] 
137. Alvaro, A.; Solà, R.; Rosales, R.; Ribalta, J.; Anguera, A.; Masana, L.; Vallvé, J.C. Gene expression analysis of a human enterocyte cell line reveals downregulation of cholesterol biosynthesis in response to short-chain fatty acids. IUBMB Life 2008, 60, 757-764. [CrossRef] [PubMed]

138. Luo, J.; Yang, H.; Song, B.L. Mechanisms and regulation of cholesterol homeostasis. Nat. Rev. Mol. Cell Biol. 2020, 21, 225-245. [CrossRef]

139. Marcil, V.; Delvin, E.; Seidman, E.; Poitras, L.; Zoltowska, M.; Garofalo, C.; Levy, E. Modulation of lipid synthesis, apolipoprotein biogenesis, and lipoprotein assembly by butyrate. Am. J. Physiol. Gastrointest. Liver Physiol. 2002, 283, G340-G346. [CrossRef]

140. Du, Y.; Li, X.; Su, C.; Xi, M.; Zhang, X.; Jiang, Z.; Wang, L.; Hong, B. Butyrate protects against high-fat diet-induced atherosclerosis via up-regulating ABCA1 expression in apolipoprotein E-deficiency mice. Br. J. Pharmacol. 2020, 177, 1754-1772. [CrossRef]

141. Bao, Y.; Yang, Y.; Wang, L.; Gao, L.; Jiang, W.; Wang, L.; Si, S.; Hong, B. Identification of trichostatin A as a novel transcriptional up-regulator of scavenger receptor BI both in HepG2 and RAW 264.7 cells. Atherosclerosis 2009, 204, 127-135. [CrossRef]

142. Shimizu, H.; Masujima, Y.; Ushiroda, C.; Mizushima, R.; Taira, S.; Ohue-Kitano, R.; Kimura, I. Dietary short-chain fatty acid intake improves the hepatic metabolic condition via FFAR3. Sci. Rep. 2019, 9, 16574. [CrossRef]

143. Mollica, M.P.; Mattace Raso, G.; Cavaliere, G.; Trinchese, G.; De Filippo, C.; Aceto, S.; Prisco, M.; Pirozzi, C.; Di Guida, F.; Lama, A.; et al. Butyrate regulates liver mitochondrial function, efficiency, and dynamics in insulin-resistant obese mice. Diabetes 2017, 66, 1405-1418. [CrossRef] [PubMed]

144. Meex, R.C.R.; Blaak, E.E. Mitochondrial dysfunction is a key pathway that links saturated fat intake to the development and progression of NAFLD. Mol. Nutr. Food Res. 2020, e1900942. [CrossRef] [PubMed]

145. Sun, B.; Jia, Y.; Hong, J.; Sun, Q.; Gao, S.; Hu, Y.; Zhao, N.; Zhao, R. Sodium butyrate ameliorates high-fat-diet-induced non-alcoholic fatty liver disease through peroxisome proliferator-activated receptor $\alpha$-mediated activation of $\beta$ oxidation and suppression of inflammation. J. Agric. Food Chem. 2018, 66, 7633-7642. [CrossRef] [PubMed]

146. Zhai, S.; Qin, S.; Li, L.; Zhu, L.; Zou, Z.; Wang, L. Dietary butyrate suppresses inflammation through modulating gut microbiota in high-fat diet-fed mice. FEMS Microbiol. Lett. 2019, 366, fnz153. [CrossRef] [PubMed]

147. Zhou, D.; Pan, Q.; Xin, F.Z.; Zhang, R.N.; He, C.X.; Chen, G.Y.; Liu, C.; Chen, Y.W.; Fan, J.G. Sodium butyrate attenuates high-fat diet-induced steatohepatitis in mice by improving gut microbiota and gastrointestinal barrier. World J. Gastroenterol. 2017, 23 , 60-75. [CrossRef]

148. Cuthbertson, D.J.; Irwin, A.; Gardner, C.J.; Daousi, C.; Purewal, T.; Furlong, N.; Goenka, N.; Thomas, E.L.; Adams, V.L.; Pushpakom, S.P.; et al. Improved glycaemia correlates with liver fat reduction in obese, type 2 diabetes, patients given glucagonlike peptide-1 (GLP-1) receptor agonists. PLoS ONE 2012, 7, e50117. [CrossRef]

149. Trevaskis, J.L.; Griffin, P.S.; Wittmer, C.; Neuschwander-Tetri, B.A.; Brunt, E.M.; Dolman, C.S.; Erickson, M.R.; Napora, J.; Parkes, D.G.; Roth, J.D. Glucagon-like peptide-1 receptor agonism improves metabolic, biochemical, and histopathological indices of nonalcoholic steatohepatitis in mice. Am. J. Physiol. Gastrointest. Liver Physiol. 2012, 302, G762-G772. [CrossRef]

150. Zhou, D.; Chen, Y.W.; Zhao, Z.H.; Yang, R.X.; Xin, F.Z.; Liu, X.L.; Pan, Q.; Zhou, H.; Fan, J.G. Sodium butyrate reduces high-fat diet-induced non-alcoholic steatohepatitis through upregulation of hepatic GLP-1R expression. Exp. Mol. Med. 2018, 50, 1-12. [CrossRef]

151. Zhang, J.M.; Sun, Y.S.; Zhao, L.Q.; Chen, T.T.; Fan, M.N.; Jiao, H.C.; Zhao, J.P.; Wang, X.J.; Li, F.C.; Li, H.F.; et al. SCFAs-induced GLP-1 secretion links the regulation of gut microbiome on hepatic lipogenesis in chickens. Front. Microbiol. 2019, $10,2176$. [CrossRef]

152. Carracher, A.M.; Marathe, P.H.; Close, K.L. International Diabetes Federation 2017. J. Diabetes 2018, 10, 353-356. [CrossRef]

153. Vazquez, G.; Duval, S.; Jacobs, D.R., Jr.; Silventoinen, K. Comparison of body mass index, waist circumference, and waist/hip ratio in predicting incident diabetes: A meta-analysis. Epidemiol. Rev. 2007, 29, 115-128. [CrossRef] [PubMed]

154. Noureldein, M.H.; Bitar, S.; Youssef, N.; Azar, S.; Eid, A.A. Butyrate modulates diabetes-linked gut dysbiosis: Epigenetic and mechanistic modifications. J. Mol. Endocrinol. 2020, 64, 29-42. [CrossRef] [PubMed]

155. Javeed, N.; Matveyenko, A.V. Circadian Etiology of Type 2 Diabetes Mellitus. Physiology (Bethesda) 2018, 33, 138-150. [CrossRef] [PubMed]

156. McNelis, J.C.; Lee, Y.S.; Mayoral, R.; Van der Kant, R.; Johnson, A.M.F.; Wollam, J.; Olefsky, J.M. GPR43 potentiates $\beta$-cell function in obesity. Diabetes 2015, 64, 3203-3217. [CrossRef] [PubMed]

157. Regard, J.B.; Kataoka, H.; Cano, D.A.; Camerer, E.; Yin, L.; Zheng, Y.W.; Scanlan, T.S.; Hebrok, M.; Coughlin, S.R. Probing cell type-specific functions of Gi in vivo identifies GPCR regulators of insulin secretion. J. Clin. Investig. 2007, 117, 4034-4043. [CrossRef]

158. Priyadarshini, M.; Villa, S.R.; Fuller, M.; Wicksteed, B.; Mackay, C.R.; Alquier, T.; Poitout, V.; Mancebo, H.; Mirmira, R.G.; Gilchrist, A. An acetate-specific GPCR, FFAR2, regulates insulin secretion. Mol. Endocrinol. 2015, 29, 1055-1066. [CrossRef]

159. Priyadarshini, M.; Layden, B.T. FFAR3 modulates insulin secretion and global gene expression in mouse islets. Islets 2015, 7, e1045182. [CrossRef]

160. Hu, S.; Kuwabara, R.; de Haan, B.J.; Smink, A.M.; de Vos, P. Acetate and butyrate improve $\beta$-cell metabolism and mitochondrial respiration under oxidative stress. Int. J. Mol. Sci. 2020, 21, 1542. [CrossRef]

161. Hu, Y.; Liu, J.; Yuan, Y.; Chen, J.; Cheng, S.; Wang, H.; Xu, Y. Sodium butyrate mitigates type 2 diabetes by inhibiting PERK-CHOP pathway of endoplasmic reticulum stress. Environ. Toxicol. Pharmacol. 2018, 64, 112-121. [CrossRef] [PubMed] 
162. Khan, S.; Jena, G. Sodium butyrate reduces insulin-resistance, fat accumulation and dyslipidemia in type-2 diabetic rat: A comparative study with metformin. Chem. Biol. Interact. 2016, 254, 124-134. [CrossRef]

163. Oiso, H.; Furukawa, N.; Suefuji, M.; Shimoda, S.; Ito, A.; Furumai, R.; Nakagawa, J.; Yoshida, M.; Nishino, N.; Araki, E. The role of class I histone deacetylase (HDAC) on gluconeogenesis in liver. Biochem. Biophys. Res. Commun. 2011, 404, 166-172. [CrossRef] [PubMed]

164. Christiansen, C.B.; Gabe, M.B.N.; Svendsen, B.; Dragsted, L.O.; Rosenkilde, M.M.; Holst, J.J. The impact of short-chain fatty acids on GLP-1 and PYY secretion from the isolated perfused rat colon. Am. J. Physiol. Gastrointest. Liver Physiol. 2018, 315, G53-G65. [CrossRef] [PubMed]

165. Yadav, H.; Lee, J.H.; Lloyd, J.; Walter, P.; Rane, S.G. Beneficial metabolic effects of a probiotic via butyrate-induced GLP-1 hormone secretion. J. Biol. Chem. 2013, 288, 25088-25097. [CrossRef] [PubMed]

166. McBrayer, D.N.; Tal-Gan, Y. Recent Advances in GLP-1 Receptor Agonists for Use in Diabetes Mellitus. Drug Dev. Res. 2017, 78, 292-299. [CrossRef] [PubMed]

167. Roshanravan, N.; Mahdavi, R.; Alizadeh, E.; Jafarabadi, M.A.; Hedayati, M.; Ghavami, A.; Alipour, S.; Alamdari, N.M.; Barati, M.; Ostadrahimi, A. Effect of butyrate and inulin supplementation on glycemic status, lipid profile and glucagon-like peptide 1 level in patients with type 2 diabetes: A randomized double-blind, placebo-controlled trial. Horm. Metab. Res. 2017, 49, 886-891. [CrossRef] 